Journal of Bangladesh Chemical Society, Vol. 24(2), 165-172, 2011.

DOI: 10.3329/jbcs.v24i2.9705

\title{
DETERMINATION OF ESSENTIAL AND TOXIC METALS IN MEATS, MEAT PRODUCTS AND EGGS BY SPECTROPHOTOMETRIC METHOD
}

M. ZAHURUL ALAM CHOWDHURY ${ }^{A}$, ZAINUL ABEDIN SIDDIQUE ${ }^{A}$, S.M. AFZAL HOSSAIN $^{\mathrm{A}}$, AZIZUL ISLAM KAZI ${ }^{\mathrm{B}}$, M. AMINUL AHSAN ${ }^{\mathrm{B}}$, SHAMIM AHMED ${ }^{\mathrm{B}}$ AND M. MAHBUB ZAMAN ${ }^{\mathrm{C}}$

${ }^{a}$ Department of Chemistry, University of Chittagong, Chittagong,Bangladesh; ${ }^{b} B C S I R$ laboratories, Dhaka, Bangladesh; ${ }^{c}$ BCSIR laboratories, Chittagong, Bangladesh

\section{Abstract}

The concentration of essential metals such as $\mathrm{Fe}, \mathrm{Cu}, \mathrm{Mg}$, $\mathrm{Co}$ and $\mathrm{Zn}$ and toxic metals such as $\mathrm{Pb}, \mathrm{Cd}, \mathrm{Cr}$, As and $\mathrm{Ni}$ were determined in a number of animal meats, organ meats, meat products, and eggs by using UV-visible and atomic absorption spectrophotometry (AAS). The essential metal estimation in the investigated samples indicated the following range of concentration: Fe: $11-623 \mathrm{mg} \mathrm{kg}^{-1}, \mathrm{Cu}: 1-165 \mathrm{mg}$ $\mathrm{kg}^{-1}, \mathrm{Mg}: 16-1372 \mathrm{mg} \mathrm{kg}^{-1}$, Co: $0.01-48 \mathrm{mg} \mathrm{kg}^{-1}, \mathrm{Zn}: 15-295 \mathrm{mg} \mathrm{kg}^{-1}$. These concentrations of essential metals are in the range of human necessities. The concentrations of toxic metals in the same samples were: $\mathrm{Pb}: 0.03-43 \mathrm{mg} \mathrm{kg}^{-1}, \mathrm{Cd}$ : $0.01-8 \mathrm{mg} \mathrm{kg}^{-1}$, Cr: $0.02-5 \mathrm{mg} \mathrm{kg}^{-1}$, As: $0.004-3 \mathrm{mg} \mathrm{kg}^{-1}$ and $\mathrm{Ni}: 0.03-41 \mathrm{mg} \mathrm{kg}$ ${ }^{1}$. The concentration of arsenic in all samples was found negligible and this indicates that the investigated samples are safe from arsenic toxicity. The concentrations of other four toxic metals being very negligible in most of the samples indicate that these foodstuffs are reasonably safe from metal toxicity. However a few samples which exhibited higher concentrations of these metals above their tolerance limits are alarming for the public health and demand regular examination of these items before coming to the markets. The information obtained from the present investigation is expected to be useful to the general people of this region in selecting meats as their diets.

Keywords: Meats, Organ meats, meat products, eggs, AAS, Heavy metals concentrations.

\section{Introduction}

Metals are found in all living organisms where they play a variety of roles. Metals such as $\mathrm{Fe}, \mathrm{Cu}, \mathrm{Mg}, \mathrm{Co}, \mathrm{Zn}$ are essential for human body but chronic metabolic disturbances may occur due to the deficiency or excess of these metals ${ }^{1}$. It is important to keep the level of these metals in their proper ranges for maintaining proper metabolic functions in human body. It can be done by taking selected foods in daily diets from a list which can give information about the metal contents of different foods ${ }^{2}$. Non essential elements such as $\mathrm{Pb}, \mathrm{Cd}, \mathrm{Cr}, \mathrm{Ni}$ and $\mathrm{As}$ are considered to be toxic and their presence in the body can cause profound biochemical and neurological changes in the body ${ }^{3}$.

The sources of toxic metals in the environment are the fossil fuels, mining industries, waste disposals and municipal sewage. Farming and forestry also contribute to the metal 
content in the environment due to the uses of fertilizer, pesticide and herbicides. As a consequence of environmental pollution, the contaminants may enter the food chain. We are taking food for living. So the major route of entry of most metals into the body is through the diet. Animal meats, meat products and eggs are consumed largely by the general people of Bangladesh since they contain proteins, amino acids, minerals and vitamins. It is very essential to know the toxic metal contents in the foodstuffs we are consuming everyday. The objective of this work is to estimate the levels of toxic metals such as $\mathrm{Pb}, \mathrm{Cd}, \mathrm{As}, \mathrm{Cr}$ and $\mathrm{Ni}$ as well as essential metals such as $\mathrm{Fe}, \mathrm{Cu}, \mathrm{Mg}$, Co and $\mathrm{Zn}$ in these foods.

\section{Experimental}

\section{Sample preparation}

Animal meats (local cow, Indian cow, buffalo, goat, local hen and farm hen), organ meats (tongue, lung, liver, spleen, and heart of cow and buffalo) were collected randomly from six different market of Chittagong city area. In the same manner the same samples were also collected from Comilla city area. Meat products (chicken burger, chicken samucha, anthon, chicken patties, chicken sandwich, beef pizza, hot dog, beef roll, chicken roll, and chicken wing) were collected randomly from six different first food shop of Chittagong city area. Meat products are usually retailed; so their origin could be varying diversified in the different shops. Egg samples (egg of local hen, farm hen and duck) were collected from Chittagong city area. Yolk and white portion of an egg analyzed separately.

The solutions of these samples were prepared by wet digestion method. Clean and dried solid flash samples of meat and organ meat, meat product (as it collected freshly) and boiled samples of egg were taken in a three neck round bottom flask and added $50 \mathrm{~mL}$ of $\mathrm{RD} \mathrm{H}_{2} \mathrm{O}$ with the sample. These were boiled for about four hours and then evaporated the solvent. At room temperature $100 \mathrm{~mL}$ of $\mathrm{HNO}_{3}$ and $\mathrm{HClO}_{4}$ mixture $(5: 1: \mathrm{v} / \mathrm{v})$ were added with the boiled sample. This was refluxed at $120-125^{0} \mathrm{C}$ (20 hours) until a clear solution appeared. The volume of the solution has been reduced to about $3-5 \mathrm{~mL}$ by condensation. At room temperature added few $\mathrm{mL}$ of $\mathrm{RD}_{2} \mathrm{O}$ and filtered through Whatman- 40 filter paper into a $100 \mathrm{~mL}$ volumetric flask and made up to the mark with $\mathrm{RDH}_{2} \mathrm{O}$. All the samples solution under the present investigation were prepared in similar manner and stored at room temperature for Spectroscopic measurement. A blank solution was also prepared for each group of sample by using all reagents except the sample.

\section{Analytical Techniques}

The amounts of $\mathrm{Fe}, \mathrm{Cu}$ and $\mathrm{Mg}$ in animal meats under the present investigation were determined by UV-visible double beam spectrophotometer, model Cintra, Australia. For determining the amounts of $\mathrm{Fe}, \mathrm{Cu}, \mathrm{Mg}, \mathrm{Co}, \mathrm{Zn}, \mathrm{Pb}, \mathrm{Cd}, \mathrm{Cr}$ and $\mathrm{Ni}$ in rest of the samples, an atomic absorption flame emission spectrophotometer, model AAS-240FS Varian Australia was used. The concentration of As in all samples was determined by hydride vapor generation of Atomic absorption graphite emission spectrophotometer, model AA- 
6401F, Shimadzu, Japan. The analysis was carried out using respective hollow cathode lamps under standard instrumental conditions (Table: 2). All the spectroscopic measurements of the standard metal solutions as well as the sample solutions were done at their respective wavelength of maximum absorptions $\lambda_{\max }$. The accuracy of the instrumental methods and analytical procedures were checked by duplications of the samples, as well as by using the independent reference standard solutions (Table 3). Moreover, the known concentration of an independent respective metal solution is measured periodically with the measurement of sample solution. When the measured value of the standard metal solution had shown deviation more then ten percent from its known concentration then recalibration had done for the respective metal. Thus the accuracy and precession of the analytical data were strictly followed throughout the present study. The detection limit of the element for the instrument and the spike recovery rates of the elements analyzed under the experimental conditions were determined (Table 4).

\section{Reagents and Solutions}

The chemicals and reagents used for the analysis were of the AR grade and redistilled water $\left(\mathrm{RD} \mathrm{H}_{2} \mathrm{O}\right)$ was used in preparation and dilution of all the solutions. $\mathrm{HClO}_{4}$ and $\mathrm{HNO}_{3}$ were procured from E. Merk, Germany. The necessary standard metal solutions were prepared in ppm level for constructing a calibration curves of $\mathrm{Mg}, \mathrm{Fe}$ and $\mathrm{Cu}$ by UV-Visible spectrophotometer (Table: 1). $1000 \mathrm{ppm}$ spectral solutions of $\mathrm{Fe}, \mathrm{Cu}, \mathrm{Mg}$, $\mathrm{Co}, \mathrm{Zn}, \mathrm{Pb}, \mathrm{Cd}, \mathrm{Cr}$, As and $\mathrm{Ni}$ for AAS were obtained from $\mathrm{BDH}$, England, for calibration purpose. All working solutions were prepared by de-ionized water. The respective metal concentrations were determined from each of the corresponding calibration curves.

\section{Results and Discussion}

It appears that there was a high content of $\mathrm{Fe}\left(11.36-623.12 \mathrm{mg} \mathrm{kg}^{-1}\right)$ in all foodstuffs. The highest level of $\mathrm{Cu}$ was found in meat products (Table: 7 ) and the lowest value was found in eggs (Table: 8). Rest of the samples contain adequate level of $\mathrm{Cu}$. Although $\mathrm{Cu}$ is essential element in trace amount but can be toxic when it exceeds the maximum permissible limit. Copper is responsible for hyperactivity in autistic children. The concentration of Co was found in the ranged $0.01-5.13 \mathrm{mg} \mathrm{kg}^{-1}$ but only beef roll of meat products contained $48.3 \mathrm{mg} \mathrm{kg}^{-1}$. The concentration of $\mathrm{Zn}$ was found to be 14.89 to $295.36 \mathrm{mg} \mathrm{kg}^{-1}$. Zinc was found excessively in most food items. Zinc is an essential trace element for animals, being involved in protein synthesis and as a constituent of many metalloenzymes ${ }^{4}$. The concentration of $\mathrm{Mg}$ in most of the samples was found higher than the other essential metals. This indicates that all the investigated samples are very good sources of $\mathrm{Mg}$. The recommended daily allowance (RDA) of $\mathrm{Fe}, \mathrm{Cu}, \mathrm{Mg}, \mathrm{Co}$ and $\mathrm{Zn}$ are $10-15,1.5-3.2,300-500,1-1.5$ and 12-15 mg per day respectively for an adult person. The study revealed that the concentration of the metals in the foodstuffs are in the range of 
human necessities on the basis of their recommended daily allowance and the people should not worry about them except in the case where their deficiency produces diseases ${ }^{2}$.

Table 1. Operating parameters of AAS used in the analysis of trace metals

\begin{tabular}{|c|c|c|c|c|c|c|c|c|c|c|}
\hline Condition & $\mathrm{Fe}$ & $\mathrm{Cu}$ & $\mathrm{Mg}$ & Co & $\mathrm{Zn}$ & $\mathrm{Pb}$ & $\mathrm{Cd}$ & As & $\mathrm{Cr}$ & $\mathrm{Ni}$ \\
\hline Wavelength (nm) & 248.3 & 324.8 & 285.2 & 240.7 & 213.9 & 217 & 228.8 & 193.3 & 357.9 & 232 \\
\hline Slit (nm) & 0.5 & 0.5 & 0.5 & 0.2 & 1.0 & 1.0 & 0.5 & 0.5 & 0.2 & 0.2 \\
\hline Lamp Current (m A) & 4 & 4 & 4 & 7 & 5 & 10 & 4 & 10 & 7 & 4 \\
\hline Air flow $(\mathrm{L} / \mathrm{m})$ & 13.5 & 13.5 & 13.5 & 13.5 & 13.5 & 13.5 & 13.5 & 13.5 & 13.5 & 13.5 \\
\hline Acetylene flow $(\mathrm{L} / \mathrm{m})$ & 2.0 & 2.0 & 2.0 & 2.0 & 2.0 & 2.0 & 2.0 & 2.1 & 2.0 & 2.0 \\
\hline
\end{tabular}

Table 2. Accuracy of the analytical data with reference to the NIST standard

\begin{tabular}{|c|c|c|c|c|c|c|c|c|c|}
\hline Name of the metal & $\mathrm{Fe}$ & $\mathrm{Cu}$ & $\mathrm{Mg}$ & $\mathrm{Co}$ & $\mathrm{Zn}$ & $\mathrm{Pb}$ & $\mathrm{Cd}$ & $\mathrm{Cr}$ & $\mathrm{Ni}$ \\
\hline Certified Value (ppm) & \multirow{3}{*}{$\begin{array}{l}1 \\
0.974 \\
\pm(0.007\end{array}$} & \multirow{2}{*}{0.2} & \multirow{2}{*}{0.1} & \multirow{2}{*}{0.5} & \multirow{2}{*}{0.2} & \multirow{2}{*}{0.5} & \multirow{2}{*}{0.2} & \multirow{2}{*}{0.5} & \multirow{2}{*}{0.5} \\
\hline Measured Value (ppm) & & & & & & & & & \\
\hline Deviation (\%) & & $\begin{array}{c}0.196 \\
0.003\end{array}$ & $\begin{array}{l}0.104 \\
0.003\end{array}$ & $\begin{array}{l}0.496 \\
0.004\end{array}$ & $\begin{array}{l}0.196 \\
0.001\end{array}$ & $\begin{array}{l}0.534 \\
0.01\end{array}$ & $\begin{array}{l}0.197 \\
0.002\end{array}$ & $\begin{array}{c}0.504 \\
0.017\end{array}$ & $\begin{array}{c}0.491 \\
0.008)^{*}\end{array}$ \\
\hline & 2.6 & 2 & 4 & 0.8 & 2 & 6.8 & 1.5 & 0.8 & 1.8 \\
\hline
\end{tabular}

* Measured values are mean \pm SD of seven replicate analyses

Table 3. Detection limit (DL) and Spikes recovery of the metals

\begin{tabular}{|l|cccccccccc|}
\hline Metals & $\mathrm{Fe}$ & $\mathrm{Cu}$ & $\mathrm{Mg}$ & $\mathrm{Co}$ & $\mathrm{Zn}$ & $\mathrm{Pb}$ & $\mathrm{Cd}$ & $\mathrm{As}$ & $\mathrm{Cr}$ & $\mathrm{Ni}$ \\
\hline DL(ppm) & 0.01 & 0.01 & 0.01 & 0.01 & 0.003 & 0.03 & 0.002 & 0.0003 & 0.05 & 0.02 \\
Recovery (\%) & $92-97$ & $90-99$ & $93-103$ & $93-102$ & $93-97$ & $93-100$ & $95-103$ & $95-101$ & $90-97$ & $96-102$ \\
\hline
\end{tabular}

Table 4. Standard compounds used for the $\lambda_{\max }$ and calibration curves (UV-visible Spectroscopy)

\begin{tabular}{|l|lccc|}
\hline Element & Standard Compounds & $\begin{array}{c}\text { Reference } \\
/ \lambda_{\max }\end{array}$ & $\begin{array}{c}\text { Measured } \\
/ \lambda_{\max }\end{array}$ & $\begin{array}{c}\text { Slit Width } \\
/ \mathrm{nm}\end{array}$ \\
\hline $\mathrm{Fe}$ & $\mathrm{FeNH}_{4}(\mathrm{SO} 4)_{2}$ & 510 & 509.23 & 1.5 \\
$\mathrm{Cu}$ & $\mathrm{CuSO}_{4} \cdot 5 \mathrm{H}_{2} \mathrm{O}$ & 435 & 435.62 & 1.5 \\
$\mathrm{Mg}$ & $\mathrm{MgSO}_{4} \cdot 7 \mathrm{H}_{2} \mathrm{O}$ & 520 & 527.25 & 1.5 \\
\hline
\end{tabular}


Table 5. Amounts $\left(\mathrm{mg} \mathrm{kg}^{-1}\right)$ of essential and toxic metals in animal meats

\begin{tabular}{|c|c|c|c|c|c|c|c|c|c|c|c|}
\hline Location & Meat of animal & $\mathrm{Fe}$ & $\mathrm{Cu}$ & $\mathrm{Mg}$ & $\mathrm{Co}$ & $\overline{Z n}$ & $\overline{\mathrm{Pb}}$ & $\mathrm{Cd}$ & As & $\mathrm{Cr}$ & $\mathrm{Ni}$ \\
\hline \multirow{12}{*}{ 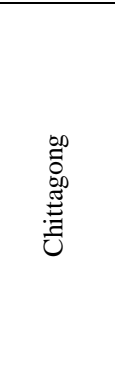 } & \multirow{2}{*}{ Cow (Local) } & 198.55 & 11.51 & 483.23 & 4.0 & 200.20 & 24.9 & 8.04 & \multirow[t]{2}{*}{0.18} & 1.22 & 2.64 \\
\hline & & $\pm(7.56$ & 1.35 & 10.93 & 0.06 & 0.08 & 0.04 & 0.002 & & 0.02 & $0.007)$ \\
\hline & \multirow[t]{2}{*}{ Cow (Indian) } & 49.53 & 2.13 & 212.74 & 1.0 & 43.09 & 2.05 & 1.57 & \multirow[t]{2}{*}{0.14} & 2.55 & $\mathrm{BDL}$ \\
\hline & & $\pm(2.12$ & 0.72 & 7.52 & 0.01 & 0.02 & 0.01 & 0.003 & & $0.004)$ & \\
\hline & \multirow[t]{2}{*}{ Buffalo(Local) } & 176.35 & 6.01 & 522.30 & 1.43 & 135.15 & 3.06 & 0.57 & \multirow[t]{2}{*}{0.16} & 5.36 & 0.13 \\
\hline & & $\pm(8.41$ & 0.52 & 3.23 & 0.05 & 0.06 & 0.12 & 0.04 & & 0.01 & $0.003)$ \\
\hline & \multirow[t]{2}{*}{ Goat (Local) } & 33.43 & 3.92 & 281.47 & 1.28 & 82.33 & 1.35 & 0.15 & \multirow[t]{2}{*}{0.33} & 0.08 & 0.35 \\
\hline & & $\pm(3.13$ & 1.62 & 3.51 & 0.04 & 0.05 & 0.004 & 0.006 & & 0.003 & 0.001 \\
\hline & \multirow[t]{2}{*}{ Cock (Local) } & 60.27 & 10.33 & 649.68 & 2.30 & 168.7 & 41.94 & 5.20 & \multirow[t]{2}{*}{0.08} & 0.69 & 1.13 \\
\hline & & $\pm(5.33$ & 1.45 & 17.32 & 0.02 & 0.07 & 0.003 & 0.002 & & 0.001 & $0.04)$ \\
\hline & \multirow[t]{2}{*}{ Cock (Farm) } & 22.46 & 3.15 & 281.86 & 2.65 & 22.77 & 0.81 & 0.11 & \multirow[t]{2}{*}{0.06} & BDL & 0.72 \\
\hline & & $\pm(4.53$ & 1.21 & 10.53 & 0.03 & 0.01 & 0.003 & 0.001 & & & $0.002)$ \\
\hline \multirow{12}{*}{$\begin{array}{l}\stackrel{\Xi}{\vec{\Xi}} \\
\text { 己ें }\end{array}$} & \multirow[t]{2}{*}{ Cow (Local) } & 131.69 & 1.88 & 390.13 & 2.87 & 152.88 & 0.29 & 0.01 & \multirow[t]{2}{*}{0.04} & BDL & 3.4 \\
\hline & & $\pm(11.54$ & 0.55 & 13.25 & 0.52 & 0.004 & 0.005 & & & & $0.24)$ \\
\hline & \multirow[t]{2}{*}{ Cow (Indian) } & 53.11 & 31.78 & 260.72 & 0.04 & 77.08 & 43.37 & 0.41 & \multirow[t]{2}{*}{0.02} & 0.02 & 41.4 \\
\hline & & $\pm(6.21$ & 5.21 & 11.21 & 0.001 & 0.002 & 0.01 & 0.001 & & & 0.01 \\
\hline & \multirow[t]{2}{*}{ Buffalo (Local) } & 143.87 & 4.47 & 472.18 & 0.23 & 76.92 & 0.64 & BDL & \multirow[t]{2}{*}{0.49} & BDL & 4.94 \\
\hline & & $\pm(5.46$ & 0.52 & 4.23 & 0.08 & 0.003 & 0.08 & & & & $0.31)$ \\
\hline & \multirow[t]{2}{*}{ Goat (Local) } & 27.17 & 5.90 & 238.62 & BDL & 58.28 & 1.36 & 0.05 & \multirow[t]{2}{*}{ BDL } & 0.37 & BDL \\
\hline & & $\pm(2.21$ & 1.23 & 5.57 & 0.002 & 0.001 & $0.0002)$ & & & & \\
\hline & \multirow[t]{2}{*}{ Cock (Local) } & 16.65 & 1.27 & 426.96 & 0.22 & 111.20 & 0.08 & 0.01 & \multirow[t]{2}{*}{ BDL } & \multirow[t]{2}{*}{ BDL } & \multirow[t]{2}{*}{ BDL } \\
\hline & & $\pm(3.45$ & 1.02 & 18.23 & 0.04 & 0.06 & $0.02)$ & & & & \\
\hline & \multirow[t]{2}{*}{ Cock (Farm) } & 23.85 & 1.82 & 401.86 & 0.84 & 14.89 & 0.03 & BDL & \multirow[t]{2}{*}{0.01} & \multirow[t]{2}{*}{ BDL } & 0.03 \\
\hline & & $\pm(5.24$ & 0.63 & 20.21 & 0.001 & 0.003 & 0.0002 & & & & 0.0002 ) \\
\hline
\end{tabular}

\pm indicates SD of three replicate measurements

Table 6. Amounts $\left(\mathrm{mg} \mathrm{kg}^{-1}\right)$ of essential and toxic metals in the organ meats of cow and buffalo of Chittagong City area

\begin{tabular}{|c|c|c|c|c|c|c|c|c|c|c|c|}
\hline Animal & Organ & $\mathrm{Fe}$ & $\mathrm{Cu}$ & $\mathrm{Mg}$ & Co & $\mathrm{Zn}$ & $\mathrm{Pb}$ & $\mathrm{Cd}$ & As & $\mathrm{Cr}$ & $\mathrm{Ni}$ \\
\hline \multirow{10}{*}{ Cow } & \multirow{2}{*}{ Tongue } & 36.75 & 0.17 & 105.13 & 1.60 & 41.11 & 0.75 & \multirow{2}{*}{ BDL } & \multirow[t]{2}{*}{0.01} & 0.06 & \multirow{2}{*}{ BDL } \\
\hline & & $\pm(0.02$ & 0.03 & 0.05 & 0.002 & 0.001 & 0.001 & & & $0.002)$ & \\
\hline & \multirow[t]{2}{*}{ Heart } & 33.54 & 0.54 & 81.62 & 5.13 & 263.64 & 0.67 & 0.06 & \multirow[t]{2}{*}{0.03} & 0.86 & 1.15 \\
\hline & & $\pm(0.03$ & 0.03 & 0.002 & 0.004 & 0.01 & 0.003 & 0.002 & & 0.005 & $0.003)$ \\
\hline & \multirow[t]{2}{*}{ Lung } & 99.31 & BDL & 82.78 & 0.01 & 22.47 & 16.3 & 1.12 & \multirow[t]{2}{*}{0.15} & 0.10 & \multirow[t]{2}{*}{ BDL } \\
\hline & & $\pm(0.01$ & & 0.01 & 0.002 & 0.004 & 0.01 & 0.002 & & 0.003 ) & \\
\hline & \multirow[t]{2}{*}{ Liver } & 99.29 & 0.81 & 59.65 & 1.05 & 20.09 & 0.72 & 0.03 & \multirow{2}{*}{0.01} & BDL & \multirow[t]{2}{*}{ BDL } \\
\hline & & $\pm(0.02$ & 0.001 & 0.004 & 0.003 & 0.004 & 0.002 & 0.0001 & & & \\
\hline & \multirow[t]{2}{*}{ Spleen } & 123.3 & 0.15 & 49.61 & 3.28 & 29.24 & 5.5 & 0.35 & \multirow[t]{2}{*}{0.11} & 0.08 & 0.43 \\
\hline & & $\pm(0.85$ & 0.05 & 1.05 & 0.23 & 1.21 & 1.03 & 0.04 & & 0.03 & $0.25)$ \\
\hline \multirow{10}{*}{ Buffalo } & \multirow[t]{2}{*}{ Tongue } & 43.16 & 1.71 & 81.17 & 1.24 & 288.46 & 7.47 & 0.75 & \multirow[t]{2}{*}{0.08} & 0.71 & BDL \\
\hline & & $\pm(0.003$ & 0.003 & 0.002 & 0.001 & 0.002 & 0.004 & 0.005 & & $0.002)$ & \multirow{3}{*}{ BDL } \\
\hline & \multirow[t]{2}{*}{ Heart } & 56.95 & 0.25 & 100.5 & 3.28 & 25.76 & 0.51 & 0.25 & \multirow[t]{2}{*}{ BDL } & BDL & \\
\hline & & $\pm(0.03$ & 0.002 & 0.004 & 0.001 & 0.004 & 0.002 & 0.001 & & & \\
\hline & \multirow[t]{2}{*}{ Lung } & 48.98 & 1.68 & 32.91 & 1.75 & 295.36 & 4.7 & 0.44 & \multirow[t]{2}{*}{0.07} & 0.44 & \multirow{2}{*}{$\begin{array}{l}0.05 \\
0.002)\end{array}$} \\
\hline & & $\pm(0.04$ & 0.005 & 0.01 & 0.003 & 0.006 & 0.001 & 0.005 & & 0.003 & \\
\hline & \multirow[t]{2}{*}{ Liver } & 85.2 & 2.44 & 16.11 & 2.84 & 160.76 & 0.98 & 0.15 & \multirow[t]{2}{*}{ BDL } & 0.93 & 0.64 \\
\hline & & $\pm(0.02$ & 0.001 & 0.006 & 0.003 & 0.004 & 0.002 & 0.001 & & 0.001 & $0.002)$ \\
\hline & \multirow[t]{2}{*}{ Spleen } & 100.6 & 0.20 & 75.75 & 2.72 & 44.81 & 4.53 & 0.25 & \multirow[t]{2}{*}{ BDL } & 1.57 & 0.17 \\
\hline & & $\pm(2.35$ & 0.02 & 4.03 & 0.41 & 2.34 & 1.24 & 0.03 & & 0.6 & $0.03)$ \\
\hline
\end{tabular}


Table 7. Amounts $\left(\mathrm{mg} \mathrm{kg}^{-1}\right)$ of essential and toxic metals in meat products (first foods) of Chittagong city area

\begin{tabular}{|l|llllllllll|}
\hline Meat products & $\mathrm{Fe}$ & $\mathrm{Cu}$ & $\mathrm{Mg}$ & $\mathrm{Co}$ & $\mathrm{Zn}$ & $\mathrm{Pb}$ & $\mathrm{Cd}$ & $\mathrm{As}$ & $\mathrm{Cr}$ & $\mathrm{Ni}$ \\
\hline Chicken Burger & 11.36 & 0.91 & 27.88 & 0.10 & 17.20 & $\mathrm{BDL}$ & 0.006 & 0.01 & 4.15 & $\mathrm{BDL}$ \\
& $\pm(0.004$ & 0.002 & 0.003 & 0.001 & 0.004 & 0.001 & 0.005 & & $0.002)$ & \\
Chicken Samucha & 219.44 & 7.07 & 280.51 & 1.05 & 34.04 & 1.46 & 0.003 & 0.004 & 3.76 & 1.75 \\
& $\pm(0.003$ & 0.005 & 0.003 & 0.001 & 0.002 & 0.007 & 0.002 & & 0.002 & $0.003)$ \\
Anthon & 599.84 & 108.56 & 454.98 & 1.18 & 284.65 & $\mathrm{BDL}$ & 0.14 & 0.008 & 3.91 & 4.85 \\
& $\pm(0.001$ & 0.003 & 0.003 & 0.001 & 0.002 & 0.005 & 0.005 & & 0.002 & $0.004)$ \\
Chicken Patties & 294.02 & 16.90 & 355.41 & 0.03 & 35.76 & $\mathrm{BDL}$ & 0.23 & 0.008 & 4.33 & 3.72 \\
& $\pm(0.007$ & 0.002 & 0.004 & 0.001 & 0.002 & & 0.004 & & 0.005 & $0.002)$ \\
Chicken Sandwich & 171.14 & 0.75 & 332.52 & 2.03 & 18.36 & $\mathrm{BDL}$ & 0.20 & $\mathrm{BDL}$ & 3.23 & $\mathrm{BDL}$ \\
& $\pm(0.004$ & 0.003 & 0.006 & 0.001 & 0.003 & & 0.004 & & $0.002)$ & \\
Beef Pizza & 230.27 & 8.27 & 341.51 & 0.03 & 37.85 & 2.45 & 0.006 & $\mathrm{BDL}$ & 2.89 & $\mathrm{BDL}$ \\
Hot Dog & $\pm(0.005$ & 0.005 & 0.004 & 0.005 & 0.008 & 0.004 & 0.005 & & $0.007)$ & \\
Beef Roll & 172.41 & 110.90 & 344.02 & 0.01 & 65.55 & 1.01 & 0.009 & $\mathrm{BDL}$ & 3.05 & 0.49 \\
& $\pm(0.003$ & 0.006 & 0.002 & 0.001 & 0.002 & 0.008 & 0.005 & & 0.002 & $0.001)$ \\
Chicken Roll & 93.47 & 165.02 & 341.77 & 48.3 & 112.67 & 4.62 & 0.003 & 2.73 & BDL & 2.73 \\
& $\pm(0.007$ & 0.008 & 0.002 & 0.001 & 0.003 & 0.004 & 0.005 & & & $0.008)$ \\
Chicken Wing & 290.09 & 97.28 & 332.59 & 0.11 & 62.03 & $\mathrm{BDL}$ & 0.016 & $\mathrm{BDL}$ & $\mathrm{BDL}$ & 0.23 \\
& $\pm(0.003$ & 0.006 & 0.002 & 0.001 & 0.002 & 0.008 & 0.005 & & & $0.003)$ \\
& 623.12 & 153.80 & 1372.54 & 0.04 & 138.38 & 3.94 & 0.021 & $\mathrm{BDL}$ & $\mathrm{BDL}$ & 2.68 \\
& $\pm(0.009$ & 0.001 & 0.002 & 0.001 & 0.002 & 0.005 & 0.008 & & & $0.002)$ \\
\hline
\end{tabular}

Table 8: Amounts $\left(\mathrm{mg} \mathrm{kg}^{-1}\right)$ of essential and toxic metals in eggs of Chittagong city area

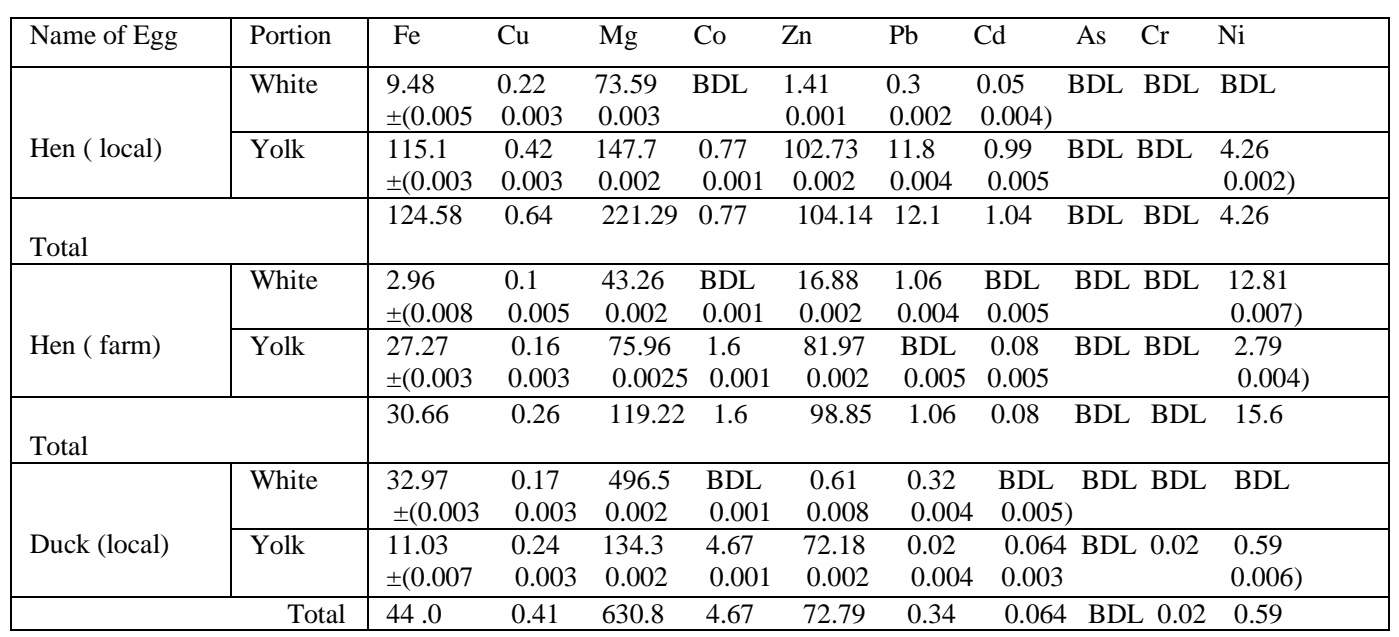

The highest concentration of $\mathrm{Pb}$ was found in animal meat of local cow and local hen of Chittagong that are 24.9 and $41.94 \mathrm{mg} \mathrm{kg}^{-1}$ respectively, whereas the highest concentration of $\mathrm{Pb}$ was found in animal meat of Indian cow and local goat of Comilla that are 43.37 and $1.36 \mathrm{mg} \mathrm{kg}^{-1}$ respectively (Table: 5). The organ meat of cow and buffalo of Chittagong contain the $\mathrm{Pb}$ in the ranges of 0.67 to $16.3 \mathrm{mg} \mathrm{kg}^{-1}$ and 0.51 to $7.47 \mathrm{mg} \mathrm{kg}^{-1}$ respectively (Table: 6). Beef roll, chicken wing, and beef pizza contain higher amount of $\mathrm{Pb}$ among the meat products, their values are $4.62,3.94$ and $2.45 \mathrm{mg} \mathrm{kg}^{-}$ ${ }^{1}$ respectively (Table:7). The amount of $\mathrm{Pb}$ in egg is very negligible except the egg of 
local hen (12.1 $\mathrm{mg} \mathrm{kg}^{-1}$ ) (Table: 8). The recommended daily allowance of $\mathrm{Pb}$ is $0.3 \mathrm{mg}$ per day ${ }^{5}$ and the maximum permissible limit (MPL) of $\mathrm{Pb}$ in food stuff is $1-5 \mathrm{mg} \mathrm{kg}^{-1}$. It was revealed from the study that few of the meat samples (Table: 5) contain significantly higher amount of $\mathrm{Pb}$ than those studied in USA, Canada, Slovenia, Spain and Palestine ${ }^{7-\mathrm{H} 1}$. But meat products, eggs and most of the meats are safe to human health considering the RDA and MPL value of $\mathrm{Pb}$. $\mathrm{Pb}$ is stored mainly in the liver and kidney. Lead toxicity affects directly the activities of different enzymes working in the body 12 . The concentration of $\mathrm{Cd}$ in animal meat of Chittagong and Comilla city are in the ranges $0.11-8.05 \mathrm{mg} \mathrm{kg}^{-1}$ and 0.01 to $0.41 \mathrm{mg} \mathrm{kg}^{-1}$ respectively (Table: 5). The amount of the metal in organ meat of cow and buffalo are in the ranges $0.03-1.12$ and $0.15-0.75 \mathrm{mg} \mathrm{kg}^{-1}$ respectively (Table: 6). The RDA of Cd is $0.2 \mathrm{mg}$ per day and the MPL for cadmium in muscle of livestock and poultry is $0.2 \mathrm{mg} \mathrm{kg}^{-1} 13,14$. The concentration of $\mathrm{Cd}$ in meat products and in eggs is within the RDA and MPL value. Cd content in some meats (Table: 5) is significantly higher and these are not safe to human health. When the concentration of $\mathrm{Cd}$ in diet is higher than RDA and MPL value, it accumulates especially in the kidney and the liver that can cause serious biological and neurological changes in human body even at ultratrace level ${ }^{3}$. The concentration of As in the studied samples were found below the RDA limits, even the amount in most of samples was below the detection limit that indicates these foodstuffs are not harmful for human health in terms of arsenic toxicity.

The concentration of $\mathrm{Cr}$ in animal meat, organ meat and meat products are in the ranges $0.02-5.36 \mathrm{mg} \mathrm{kg}^{-1}, 0.06-1.57 \mathrm{mg} \mathrm{kg}^{-1}$ and $2.89-4.33 \mathrm{mg} \mathrm{kg}^{-1}$ respectively and the amounts are within the permissible limit in eggs(Table: 5-7). The investigation shows that the concentration of $\mathrm{Cr}$ in the meat products and a very limited number of meats of Chittagong city is significantly higher than those studied in abroad. Chromium, particularly $\mathrm{Cr}$ (III) plays an important role in the body function (metabolic functions, cofactor of insulin etc.) in trace amount but it turns to be toxic when it exceeds the tolerance limit. $\mathrm{Cr}(\mathrm{VI})$ is toxic and has no beneficial role in human body ${ }^{12}$. The highest amount of Nickel was found in animal meats of local cow $\left(2.64 \mathrm{mg} \mathrm{kg}^{-1}\right)$ of Chittagong city followed by local hen $\left(1.13 \mathrm{mg} \mathrm{kg}^{-1}\right)$ (Table: 5). The egg of firm hen shows the highest amount of $\mathrm{Ni}\left(15.6 \mathrm{mg} \mathrm{kg}^{-1}\right)$ followed by egg of local hen $\left(4.26 \mathrm{mg} \mathrm{kg}^{-1}\right)$ (Table: 8). Anthon, chicken patties, beef roll, chicken wing of meat products contain 4.85, 3.72, $2.73,2.68 \mathrm{mg} \mathrm{kg}^{-1}$ of $\mathrm{Ni}$ respectively (Table: 7). The presence of $\mathrm{Ni}$ in rest of the samples is negligible compared to the RDA value of $\mathrm{Ni}$ and are safe from the $\mathrm{Ni}$ toxicity. The study reveals that few of the foods contain higher amount of Ni. Appropriate amount of $\mathrm{Ni}$ in human body plays roles in regulating of prolactine and stabilization of RNA and DNA structures ${ }^{12}$. Excessive intake of Ni produces severe allergic reaction, bronchial asthma, dermatitis, aczema and myocardial infection ${ }^{15}$.

\section{Conclusion}

The study reveals that meats, meat products and eggs are the good sources of macro and micro nutrients and also most of the studied foodstuffs contain the toxic elements within consumable limits. Another important point is that all the studied food items are safe 
from arsenic toxicities. But some of the food items bear noticeable amount of toxic metals such as $\mathrm{Pb}, \mathrm{Cd}, \mathrm{Cr}$ and $\mathrm{Ni}$. The present study suggests avoiding those foods as much as possible. Moreover, concerned authority should take necessary steps for reducing the toxic metal contamination into the food chain. This study also provided baseline data on toxic metal concentrations for meats, meat products and eggs in this region of Bangladesh.

\section{Acknowledgement}

Authors would like to thank to the University of Chittagong, analytical research division of BCSIR laboratories of Chittagong and Dhaka for providing their technical assistance and instrumental facilities. The authors are also grateful for the overall assistance to the University Grant Commission and Ministry of Education of Bangladesh.

\section{Reference}

1. W. Martz, “The essential trace elements”, Science, 1981, 213, 1332-37.

2. M.Z.A. Chowdhury, M. Monir Uddin, M. Faridul Alam, M. Reaz Uddin, M. Jakir Hossain and M. Shahidul Alam, Pak. J. Anal. Chem., 2003, 4(2), 99-103.

3. F.H. Nielsen, "Ultra traces elements in human nutrition" A.R. Diss., Inc., New York. 1982, 379-404.

4. E.J. Underwood, "Trace elements in human and animal nutrition", $4^{\text {th }}$ edition., Academic Press, New York, 1977.

5. D.Gonzaacutlez-Weller, A.Caballero, F. Hernaacutendez, A. Gutleacuterrez, T. Gonzaacutelez-Iglessis, M. Marino and A. Hardisson, Food Additives \& Contaminants, Part A. Volume 23, Issue: 8, 2006, 757-763.

6. IAEA, "Elemental analysis of Biological Materials" (Technical Report Series No. 197) IAEA Vienna, 1980.

7. J.M. Llo Bet, G. Falco, C. Cass, A. Tlixido, and J.L.Domingo, J. Agric. Food Chem., 2003, 57, 838-842.

8. R.L. Bordajandi, G. Gmez, E.Abad, J.Rivera, M.D.M. Fernndez-Bastn, J.Blasco and M.J. Gonzlez, J. Agric Food Chem., 2004, 52 ( 4), 992-1001.

9. C.Rubio, T.Gonzalez- Iglesias, C.Rovert, I.J.Reguera, J.A.Gutierrez, and A.Hardisson, J. Agric. Food Chem., 2005, 53, 6543-6549.

10. H.M. Chan, C.Kim, K.Khoday, O.Receveur and H.V.Kuhlein, Environmental Health Perspectives, 1995, 103(7/8), 740-746.

11. R. Milacic and B.Kralj, Eur Food Technol, 2003, (217), 211-214.

12. J.S. Khurshid and H. Q. Iqbal "The role of inorganic elements in the human body" Nucleus, 1984, 21, 3-23.

13. L.J.Cassarett and J. Doull, "Toxicology, The basic Science of Poisons" $2^{\text {nd }}$ ed., 409-467, Macmillan Publishing Co. Inc., NY, 1980.

14. A.B. Mancean, M.L.L.Schlegal, J.C.Harge, M.Musso, and L.Eybertberard, Am. J. Sci., 2000, 300, 289-343.

15. C.R.K. Murtic and P. Viswanathan, "Toxic metals in the Indian, environment" Wiley Eastern Ltd., New Dilhi, 1989. 